\title{
PERENCANAAN PENGEMBANGAN INSTRUMEN PENILAIAN SIKAP PADA APRESIASI SASTRA ANAK
}

\author{
Syihabuddin ${ }^{\text {1), }}$ Vismaia S. Damaianti ${ }^{2 \text { ), }}$ \\ N. Yeffa Afnita Apriliyani ${ }^{3)}$, Rika Istianingrum ${ }^{4)}$ \\ Universitas Pendidikan Indonesia ${ }^{1,2)}$, \\ Universitas Islam Nusantara ${ }^{3)}$, Universitas Balikpapan ${ }^{4)}$ \\ syihabuddin@upi.edu ${ }^{1)}$,. vismaia@upi.edu²), \\ yefaafnita@gmail.com ${ }^{3)}$, riekaistianingrum@gmail.com ${ }^{4)}$
}

ABSTRAK

ABSTRACT
Pembelajaran Bahasa dan Sastra Indonesia hendaknya disajikan secara utuh ke dalam aspek-aspek keterampilan berbahasa dan bersastra terutama pada pembelajaran apresiasi sastra anak. Cenderung pada sebuah pembelajaran, guru melakukan evaluasi hasil belajar secara diskrit dalam bentuk tes akhir, jarang guru melakukan evaluasi proses berupa pengamatan tingkah laku atau kita sebut dengan penilaian sikap. Pemahaman guru terhadap konsep dan implementasi penilaian sikap masih kurang maksimal, artinya adalah guru masih kesulitan dalam melakukan penilaian sikap yang diterapkan pada bentuk penilaian sikap Kurikulum 2013 yakni, penilaian observasi, jurnal harian, penilaian sejawat, penilain diri sendiri. Untuk mewujudkan suatu bentuk konsep instrumen penilaian sikap yang mudah untuk diimplementasikan dalam pembelajaran dengan memanfaatkan nilai-nilai moral pada apresiasi sastra yang berupa novel anak, maka penelitian ini bertujuan untuk mendeskripsikan nilai-nilai yang terkandung dalam sastra anak pada novel anak dapat dimanfaatkan sebagai indikator instrumen penilaian sikap yang berkaitan dengan bentuk kompetensi penilaian sikap Kurikulum 2013 serta memaparkan tahap-tahap konsep bentuk instrumen penilaian sikap pada apresiasi sastra anak yang dapat dikembangkan dari pengkajian novel anak dan didasarkan pada bentuk kompetensi penilaian sikap Kurikulum 2013. Jenis penelitian yang digunakan adalah kualitatif dengan metode research and development. Pengumpulan data dalam penelitian ini menggunakan teknik observasi, wawancara, rekam, dan studi lietratur/pustaka. Analisis data yang digunakan adalah deskriptif interpretatif. Hasil penelitian ini menunjukkan bahwa; 1) Nilai-nilai moral yang terkandung dalam sastra anak pada novel anak dapat dimanfaatkan sebagai indikator instrumen penilaian sikap. 2) Konsep bentuk instrumen penilaian sikap pada apresiasi sastra anak yang dapat dikembangkan dari pengkajian novel anak dan didasarkan pada bentuk kompetensi penilaian sikap Kurikulum 2013.

Kata Kunci: evaluasi, penilaian sikap, nilai-nilai moral, sastra anak

Indonesian language and literature learning should be presented intactly into aspects of language and literacy skills, especially in learning the appreciation of children's literature. Tend 
to a learning, teachers do discrete evaluation of learning outcomes in the form of final tests, rarely do teachers evaluate the process of behavioral observation or we call the attitude assessment. Teachers' understanding on the concept and implementation of attitude evaluation is still not maximal, meaning that teachers are still having difficulty in performing attitude assessment applied in the form of assessment of curriculum 2013 ie, observation assessment, daily journal, peer assessment, self assessment. To realize a form of concept of attitude assessment instrument that is easy to be implemented in learning by utilizing moral values on the appreciation of literature in the form of novel children, this study aims to describe the values contained in children's literature in children's novels can be used as an indicator of the instrument assessment of attitudes related to the form of competence of attitudes assessment Curriculum 2013 and describes the stages of the concept of the form of an attitude assessment instrument on the appreciation of children's literature that can be developed from the novel study of children and is based on the form of competence assessment attitude Curriculum 2013. Type of research used is qualitative with research and development. Data collection in this research use observation technique, interview, record, and lietratur / library study. The data analysis used is descriptive interpretative. The results of this study indicate that; 1 ) moral values contained in children's literature on children's novels can be used as indicators of attitude assessment instruments. 2) The concept of an attitude assessment instrument on the appreciation of children's literature that can be developed from the novel study of the child and based on the form of competency assessment of Curriculum 2013 attitudes.

Keywords: attitude assessment, moral values, children literature

PENDAHULUAN kegiatan yang memiliki peranan penting serta memberikan manfaat terhadap pencapaian hasil belajar siswa. Salah satu manfaat dari penilaian yaitu digunakan sebagai umpan balik bagi siswa maupun guru. Bagi siswa penilaian berfungsi untuk mengukur sejauh mana kemampuan siswa, sedangkan bagi guru penilaian berfungsi untuk memperbaiki kegiatan dan metode yang digunakan dalam proses pembelajaran.

Sudjana (2011:2) menjelaskan bahwa dalam penilaian hendaknya diperiksa sejauh mana perubahan tingkah laku siswa telah terjadi melalui proses belajarnya untuk mengetahui tercapai tidaknya tujuan-tujuan instruksional. Dengan perkataan lain, hasil penilaian tidak hanya bermanfaat untuk mengetahui tercapai tidaknya tujuan instruksional, dalam hal ini perubahan tingkah laku siswa, tetapi juga sebagai umpan balik bagi upaya memperbaiki proses belajar-mengajar.

Penilaian pembelajaran pada paradigma lama lebih ditekankan pada hasil yang cenderung menilai kemampuan aspek kognitif, menggunakan bentuk tes seperti pilihan ganda, benar atau salah, 
telah gagal mengetahui kinerja siswa yang sesungguhnya. Tes tersebut belum bisa mengetahui gambaran yang utuh mengenai sikap, keterampilan, dan pengetahuan siswa dikaitkan dengan kehidupan nyata mereka di luar sekolah atau masyarakat.

Nurgiyantoro (2011:25) mengatakan bahwa cara penilaian bermacam-macam, dapat menggunakan model non tes dan tes sekaligus, serta dapat dilakukan kapan saja bersamaan dengan kegiatan pembelajaran. Biasanya penilaian dilakukan dalam bentuk ujian berupa tes. Tes cenderung digunakan untuk mengukur kompetensi pada ranah kognitif dan jawabannya bersifat mutlak, sedangkan non tes lebih tepat jika digunakan untuk mengukur kompetensi kognitif dan jawabannya bersifat bebas dan tidak mutlak.

Kurikulum 2013 menuntut penilaian pembelajaran tidak hanya ditujukan untuk mengukur tingkat kemampuan kognitif semata, tetapi mencakup seluruh aspek kepribadian siswa, seperti perkembangan moral, perkembangan emosional, perkembangan sosial dan aspek-aspek kepribadian individu lainnya. Kurikulum 2013 yang mulai dilaksanakan pada tahun ajaran 2013/2014 sebenarnya mengacu pada domain Bloom dan Anderson yaitu mempertimbangkan aspek kognitif, afektif, dan psikomotor.

Tidak mengherankan bahwa ketika penilaian nasional atau lokal berubah, guru merasa bingung sebelum mencoba, mereka mengatakan terlalu banyak yang akan dinilai, terlebih siswa dengan kelas besar, kesulitan cara memulainya, terlalu banyak waktu terbuang hanya untuk menilai dan akhirnya tidak fokus mengajar. Beban yang ada dipikiran guru inilah yang membuat guru enggan melakukan penilaian autentik terhadap sikap siswa. Berdasarkan hasil pada kegiatan observasi awal dengan melakukan wawancara terhadap guru berkaitan dengan analisis kebutuhan guru terhadap penilaian sikap yang terdapat di dalam Kurikulum 2013, menunjukkan bahwa sebagian besar guru masih belum memahami penilaian sikap sehingga penilaian ini sering terabaikan oleh guru.

Berkaitan dengan analisis kebutuhan terhadap evaluasi penilaian sikap yang dilakukan oleh guru bahwa guru menginginkan instrumen penilaian sikap sebagai alat untuk evaluasi yang sederhana dan mudah dalam penerapannya, meskipun sudah menerapkan penilaian sikap namun dalam kenyataannya masih banyak guru yang merasa kesulitan dalam penyusunan instrumen penilaian tersebut.

Evaluasi yang dimaksudkan dalam penelitian ini adalah melaksanakan penilaian terhadap sikap siswa yang dibagi dalam dua kompetensi sikap yaitu sikap spiritual dan sikap sosial. Kurikulum 2013 membagi kompetensi sikap menjadi dua, yaitu sikap spiritual yang terkait dengan pembentukan peserta didik yang beriman dan bertakwa, dan sikap sosial yang terkait dengan pembentukan peserta didik yang berakhlak mulia, mandiri, demokratis, dan bertanggung jawab. Sedangkan bentuk penilaian sikap yang diterapkan pada kompetensi penilaian Kurikulum 2013 
yakni, penilaian observasi, jurnal harian, penilaian sejawat, penilain diri sendiri.

Kesulitan guru dalam memahami kriteria penilaian sikap dari pedoman penilaian sikap yang ada, membuat peneliti berusaha untuk menyusun instrumen penilaian sikap yang mudah dipahami dan mudah digunakan. Pengembangan instrumen penilaian sikap ini akan mengadopsi penilaian sikap yang sudah ada, yakni bentuk kompetensi penilaian sikap Kurikulum 2013 serta didasarkan pada nilai-nilai moral novel anak dalam pembelajaran apresiasi sastra anak

Pembelajaran Bahasa dan Sastra Indonesia dapat diartikan sebagai serangkaian aktivitas yang dilakukan siswa untuk mencapai keterampilan berbahasa serta bersastra. Keterampilan berbahasa yang terdapat dalam pembelajaran Bahasa Indonesia yaitu menyimak, berbicara, membaca, dan menulis. Salah satu kegiatan pembelajaran sastra yang harus dikuasai oleh siswa yaitu kegiatan apresiasi sastra.

Penilaian kegiatan apresiasi sastra yang cenderung memperlihatkan keterampilan hasil kerja dianggap tidak sesuai jika diukur dengan bentuk tes. Sebaliknya, kegiatan apresiasi sastra akan lebih cocok jika menggunakan sistem penilaian bentuk non tes yang tidak memiliki kemutlakan jawaban pada opsi. Hal tersebut bertujuan untuk meningkatkan kreativitas, keterampilan, pengetahuan, dan pemahaman anak tentang materi yang dipelajari. Oleh karena itu, penelitian ini menggabungkan antara pembelajaran apresiasi sastra anak terutama pada novel anak untuk dikaji mengenai nilai-nilai yang terkandung di dalam novel anak tersebut lantas hasil dari kajiannya akan digunakan sebagai indikator instrumen penilaian sikap terutama pada variabel penilaian sikap diri sendiri.

Seorang guru harus menyadari bahwa anak-anak hidup dalam masa perkembangan fisik dan mental serta perkembangan informasi dan komunikasi. Untuk menunjang semua perkembangan tersebut sastra dapat dijadikan sarana penunjang karena sastra dapat memberikan nilai-nilai tinggi bagi proses perkembangan bahasa, kognitif, personalis, dan sosial anak-anak. Sastra juga dapat dijadikan panduan pembelajaran untuk anak-anak dalam melihat apa yang terjadi disekelilingnya.

Tarigan (2011:3) mengungkapkan bahwa sastra merupakan pelukisan kehidupan atau pikiran imajinatif ke dalam bentuk dan struktur bahasa. Wilayah sastra meliputi kondisi insani atau manusiayaitu kehidupan dengan segala perasaan, pikiran, dan wawasannya.

Adapun kaitan sastra dengan anak-anak, menurut Lukers (Ampera, 2010:10) sastra menawarkan dua hal utama yaitu kesenangan dan pemahaman. Sastra hadir kepada pembaca dengan hiburan yang menyenangkan. Gambar kehidupan dalam sastra dapat memberikan pemahaman kepada pembaca tentang persoalan hidup dan kehidupan. 
Sastra anak sangat erat dengan nilai-nilai moral yang terkandung di dalam isi ceritanya. Hal tersebut dikaitkan dengan kehidupan anak-anak setiap hari karena pada dasarnya cerita merupakan realitas atau cerminan dari kehidupan. secara sederhana istilah sastra anak dapat diartikan bahwa karya seni yang imajinatif dengan unsur estetisnya dominan yang penyampaiannya melalui bahasa, baik lisan ataupun tertulis, yang secara khusus dapat dipahami oleh anak-anak dan berisi tentang dunia yang akrab dengan anak-anak.

Ampera (2010: 21) menyatakan bahwa sastra anak adalah karya sastra yang dikonsumsi anak dan diurus serta dikerjakan oleh orang tua. Pendek kata, sastra anak ditulis oleh orang tua untuk anak. Orang tua jugalah yang mengedit, mengilustrasi, mencetak, menerbitkan, mendistribusikan, memilihkannya di rumah atau di sesekali membicarakannya. Orang dewasa pulalah yang membimbing anak dalam memilih dan mengusahakan bacaan yang baik bagi anak.

Sebenarnya, tidak semua sastra anak itu ditulis oleh orang tua. Penulis sastra anak dapat juga dilakukan oleh anak-anak itu sendiri, misalnya anak yang telah berumur sepuluhatau sebelas tahun ke atas, sudah dapat menulis puisi atau catatan harian. Memang pada umumnya sastra anak itu ditulis oleh orang dewasa atau orang tua untuk anak-anak. Seperti obyek yang dikaji oleh peneliti dalam penelitian ini yaitu memanfaatkan sastra anak berupa novel anakanak berbahasa Sunda dengan judul "Rasiah Kodeu Binér" karya Dadan Sutisna, dan novel berbahasa Indonesia dengan judul "Petualangan Hati Jelajahi Pelangi” karya Sherina Salsabila.

Oleh karena itu, peneliti memanfaatkan sastra anak berupa novel anak anak-anak berbahasa Sunda dengan judul "Rasiah Kodeu Binér” karya Dadan Sutisna, dan novel berbahasa Indonesia dengan judul "Petualangan Hati Jelajahi Pelangi" karya Sherina Salsabila dijadikan sebagai konsep bentuk indikator instrumen penilaian sikap yang dibatasi pada bentuk penilaian sikap pada variabel penilaian diri sendiri dalam pembelajaran apresiasi sastra anak tingkat Sekolah Dasar. Maka, penelitian ini bertujuan untuk mendeskripsikan nilai-nilai yang terkandung dalam sastra anak pada novel anak dapat dimanfaatkan sebagai indikator instrumen penilaian sikap yang berkaitan dengan bentuk kompetensi penilaian sikap Kurikulum 2013 serta memaparkan tahap-tahap konsep bentuk instrumen penilaian sikap pada apresiasi sastra anak yang dapat dikembangkan dari pengkajian novel anak dan didasarkan pada bentuk kompetensi penilaian sikap Kurikulum 2013.

METODE

Penelitian ini menggunakan jenis penelitian kualitatif. Metode yang digunakan adalah metode penelitian Research and Development (R\&D). Sumber data dalam penelitian ini adalah guru untuk mengetahui analisis kebutuhan yang berkaitan dengan bentuk penilaian sikap pada pembelajaran apresiasi sastra, novel Rasiah Kodeu Binér karya Dadan Sutisna, dan novel Petualangan Hati Jelajahi Pelangi karya Sherina Salsabila. Pengumpulan data dalam 
penelitian ini menggunakan teknik observasi, wawancara, rekam, dan studi literatur/pustaka. Analisis data yang digunakan adalah deskriptif interpretatif. Adapun metode pengembangan yang akan diterapkan dalam penelitian ini adalah adaptasi dari konsep penelitian dan pengembangan dari Sugiyono, yakni: (1) potensi dan masalah, (2) pengumpulan data, (3) desain produk, (4) validasi desain, (5) revisi desain, (6) uji coba produk, (7) revisi produk, (8) uji coba pemakaian, (9) revisi produk, dan (10) produksi. Dalam penelitian ini, peneliti menginterpretasikan desain konsep pengembangan Sugiyono menjadi 6 tahapan, yakni: (1) Analisis kebutuhan masalah, (2) Penyusunan Spesifikasi, (3) Menentukan Skala Instrumen, (4) Melakukan skoring (5) Melakukan uji coba/uji validitas, (6) Produk. Meskipun penelitin ini adalah penelitian pengembangan instrumen penilaian sikap pada spresiasi sastra anak, namun, penelitian ini hanya sampai pada tahapan perencanaan pengembangan instrumen penilaian sikap pada apresiasi sastra anak. Dalam tahapan perencanaan pengembangan instrumen penilaian sikap yang didasarkan pada instrumen penilaian sikap pada Kurikulum 2013 serta nilai-nilai sikap atau moral dari novel novel Rasiah Kodeu Binér karya Dadan Sutisna, dan novel Petualangan Hati Jelajahi Pelangi karya Sherina Salsabila, tidak sampai dilakukan tahap uji coba/uji validitas karena sifatnya hanya sebatas penelitian perencanaan pengembangan serta memberikan contoh pembuatan instrumen penilaian sikap yang dikaitkan dengan sastra anak berupa cerita pendek/novel.

\section{PEMBAHASAN}

Berdasarkan hasil pada kegiatan observasi awal dengan melakukan wawancara terhadap guru mengenai analisis kebutuhan guru terhadap penilaian sikap yang terdapat di dalam Kurikulum 2013, menunjukkan bahwa sebagian besar guru masih belum memahami penilaian sikap sehingga penilaian ini sering terabaikan oleh guru dikarenakan terlalu banyak bentuk instrumen penilaian sikap yang diterapkan pada kompetensi penilaian Kurikulum 2013 yakni, penilaian observasi, jurnal harian, penilaian sejawat, dan penilain diri sendiri.

Banyak Guru yang mengeluh tentang banyaknya kriteria penilaian sikap tersebut dan faktor-faktor yang menghambat pelaksanaan penilaian dalam pembelajaran terutama pada kegiatan apresiasi sastra. Beberapa faktor tersebut adalah terkait sikap guru terhadap penilaian. Ada beberapa guru beranggapan penilaian subjektif itu sulit untuk digunakan, beberapa guru lain mengatakan memerlukan waktu terutama di kelas besar dan sebagian guru yang lain tidak memiliki pengetahuan tentang bagaimana untuk menilai siswa.

Ditemukan juga bahwa sebagian besar guru masih belum memahami penilaian sikap sehingga penilaian ini sering terabaikan oleh guru. Minimnya keinginan guru untuk meningkatkan kemampuan dalam melakukan penilaian autentik sikap spiritual dan sikap sosial. Hal ini dibuktikan dari hasil penelitian awal yang 
dilaksanakan oleh peneliti pada beberapa guru tingkat SD di Bandung.

Melihat data hasil penelitian pendahuluan menunjukkan seluruh guru menginginkan instrumen penilaian sikap yang sederhana dan mudah dalam penerapannya, meskipun sudah menerapkan penilaian sikap, namun dalam kenyataannya masih banyak guru yang merasa kesulitan dalam penyusunan instrumennya.

Berdasarkan analisis kebutuhan dengan observasi serta wawancara terhadap guru dapat disimpulkan bahwa kelemahan yang ada pada guru pada SD diperoleh sebagai berikut.

1. Masih bersifat universal dari bentuk penilaian yang ada.

2. Buku pegangan penilaian sikap yang ada, masih membebani guru untuk menyusun instrumen dari setiap sub indikator penilaian sikap.

3. Guru masih dibebani dengan harus menganalisis kembali capaian dari setiap indikator penilaian.

4. Penilaian sikap yang ada hanya berdasarkan subtema.

5. Indikator penilaian yang ada belum terpecah dalam setiap subtema dan pembelajaran.

6. Pencapaian penilaian sikap siswa tidak terdeskripsi.

Kesulitan guru dalam memahami kreteria penilaian sikap dari pedoman penilaian sikap yang ada, membuat peneliti berusaha untuk menyusun instrumen penilaian sikap yang mudah dipahami dan mudah digunakan. Pengembangan instrumen penilaian sikap ini akan mengadopsi penilaian sikap pada kompetensi penilaian sikap Kurikulum 2013 serta dikaitkan dengan aspek nilai-nilai moral yang terdapat di dalam karya sastra anak.

Berdasarkan hasil observasi dan wawancara terhadap guru tentang analisis kebutuhan guru terhadap penilaian sikap, maka dapat disimpulkan bahwa beberapa guru yang menjadi responden sudah melaksanakan penilaian sikap dan sudah mengikuti panduan dalam penilaian sikap namun masih saja sebagian dari responden merasa kesulitan dalam melakukan penilaian sikap.

Ketidakmampuan guru dalam melakukan penilaian sikap disebabkan oleh beberapa faktor, di antaranya adalah.

1. Kurangnya pemahaman guru terhadap teknik penilaian sikap, yang ditandai dengan banyaknya guru yang menginginkan penilaian sikap yang valid dan reliabel serta mudah digunakan.

2. Pemahaman yang diterima guru bahwa penilaian sikap hanya menggunakan teknik observasi. Padahal menurut bentuk penilaian sikap yang mengacu Kurikulum 2013 bahwa penilaian sikap tidak hanya sekedar penilaian observasi oleh guru, tetapi juga penilaian jurnal harian oleh guru, penilaian sejawat oleh siswa, dan penilain diri sendiri oleh siswa.

Maka dari itu, peneliti menyusun konsep bentuk penilaian sikap yang memanfaatkan sastra anak sebagai landasan indikator instrumennya. Sebelum menyusun konsep bentuk penilaian sikap yang memanfaatkan sastra anak berupa nilai-nilai moral pada novel 
anak, terlebih dahulu mengkaji nilai-nilai moral apa saja yang terkandung di dalam novel Rasiah Kodeu Binér karya Dadan Sutisna, dan novel Petualangan Hati Jelajahi Pelangi karya Sherina Salsabila yang terkait dengan indikator bentuk komponen penilian sikap Kurikulum 2013.

\section{Nilai-Nilai Moral pada Novel Anak}

Berdasarkan analisis kajian mengenai nilai-nilai moral pada novel anak yang berbahasa Sunda dengan judul "Rasiah Kodeu Binér” karya Dadan Sutisna dan novel anak yang berbahasa indonesia "Petualangan Hati Jelajahi Pelangi" karya Sherina Salsabila terdapat 39 bentuk nilai moral yang berkaitan dengan kehidupan bermasyarakat. Adapun bentuk nilai moral yang terdapat di dalam novel Rasiah Kodeu Binér karya Dadan Sutisna dan novel Petualangan Hati Jelajahi Pelangi karya Sherina lebih dominana pada nilai-nilai moral yang berkaitan dengan sikap toleransi, sikap tanggung jawab, sikap percaya diri, serta sikap gotong royong.

Pada novel Rasiah Kodeu Binér karya Dadan Sutisna termasuk bukan novel yang ditulis oleh anak-anak, melainkan novel yang ditulis oleh orang dewasa namun bercerita mengenai kehidupan anak-anak dengan segala hal yang dunia anak. Isi novel Rasiah Kodeu Binér menceritakan pengalaman-pengalaman anak mengenai segala hal yang berkaitan dengan kecanggihan ilmu dan teknologi serta pengetahuan. Di dalam novel Rasiah Kodeu Binér yang berbahasa daerah terdapat banyak hal amanat yang disampaikan oleh pengarang melalui isi cerita serta bahasanya untuk anak-anak serta juga untuk pembaca yang bukan dari kalangan anak-anak.

Bentuk nilai moral yang terkadung di dalam novel Rasiah Kodeu Binér karya Dadan Sutisna terdapat 24 bentuk nilai moral yang mencerminkan kehidupan sikap anak-anak pada umumnya. Adapun bentuk nilai-nilai moral tersebut antar lain; Perilaku taat beragama, bersahabat, jujur, sportif, disiplin, etos kerja, amanat, tanggung jawab, empati, mengutamakan kepentingan orang lain, adil, kooperatif, suka membantu, santun, berani mengambil resiko, pantang menyerah, cerdas, kritis, keingintahuan, kreatif inovatif, berorientasi terhadap IPTEK, bersih dan sehat, gigih, ceria.

Sedangkan pada novel Petualangan Hati Jelajahi Pelangi karya Sherina Salsabila merupakan novel anak, novel yang bercerita mengenai kehidupan anak-anak, serta yang menulis pun anak-anak. Novel Petualangan Hati Jelajahi Pelangi menceritakan realitas-realitas sosial yang berhubungan dengan seorang anak yang utama dari cara berteman anak dengan anak lainnya. Jenis hubungan ini yang akan menentukan bagaimana anak memperlakukan anak lainnya. Kepribadian anak yang utama yang dapat menentukan seorang anak mampu memperlakukan anak lainnya dengan baik. Dalam hal ini, pengarang yang masih usia anak beranjak dewasa ini, tentu saja ada banyak hal yang disampaikannya kepada pembaca bahwa seperti begini realitas kehidupan anak dengan keluarga, anak dengan teman, anak dengan 
lingkungan. Tentu saja hal ini berkaitan dengan bentuk kepribadian dan sikap pada diri anak.

Bentuk nilai moral yang terkadung di dalam novel Petualangan Hati Jelajahi Pelangi karya sherina Salsabila terdapat 15 bentuk nilai moral yang mencerminkan kehidupan sikap anak-anak pada umumnya. Adapun bentuk nilai-nilai moral tersebut antar lain; rasa peduli, menghargai, perhatian, cemburu, pemberian nasihat, rasa melindungi, rasa khawatir, persahabatan, tulus, etika, persaingan, bentuk bakti terhadap orang tua, harapan, kesadaran, menghormati.

Bentuk nilai-nilai moral yang terdapat pada novel Rasiah Kodeu Binér karya Dadan Sutisna, dan novel Petualangan Hati Jelajahi Pelangi karya Sherina Salsabila didasarkan pada bentuk kompetensi penilaian sikap Kurikulum 2013 terdapat hampir keseluruhan nilai-nilai moral dalam novel yang berkaitan dengan bentuk kompetensi penilaian sikap kurilukum 2013. Namun yang lebih dominan penilaian sikap sosial yang terdapat pada bentuk penlaian sikap Kurikulum 2013. Adapun bentuk tersebut adalah sikap tanggung jawab, sikap toleransi, siakp gotong royong, sikap percaya diri.

Dari bentuk nilai-nilai moral yang terdapat pada novel anak berbahasa daerah yaitu Sunda maupun novel anak yang berbahasa Indonesia memiliki bentuk nilai moral yang dikategorikan pada siakp atau perilaku yang mencerminkan kehidupan anak. Oleh karena itu, nilai-nilai moral dari novel-novel anak akan dimanfaatkan untuk membuat konsep bentuk instrumen penilaian sikap pada pembelajaran apresiasi sastra anak.

\section{Bentuk Instrumen Penilaian Sikap pada Apresiasi Sastra Anak}

Prosedur pengembangan instrumen penilaian untuk menghasilkan model instrumen penilaian sikap pada apresiasi sastra anak yang baik atau sesuai dengan kriteria yang telah ditetapkan, diperlukan penyusunan instrumen penilain yang dilakukan secara sistematis, melalui prosedur yang benar sesuai dengan kaidahkaidah yang baik.

Suryabrata (2012: 303) berpendapat bahwa langkah-langkah pengembangan alat ukur khususnya atribut non-kognitif, adalah: 1). Pengembangan spesifikasi alat ukur; 2). Penulisan pernyataan atau pertanyaan; 3). Penelaahan pernyataan atau pertanyaan; 4). Perakitan instrumen (untuk keperluan uji-coba); 5). Uji-coba; 6). Analisis hasil uji-coba; 7). Seleksi dan perakitan instrumen; 8). Administrasi instrumen; 9). Penyusunan skala dan norma.

Langkah penelitian dan pengembangan menurut Sugiyono (2013: 298) dengan langkah-langkah yaitu: (1) potensi dan masalah, (2) pengumpulan data, (3) desain produk, (4) validasi desain, (5) revisi desain, (6) uji coba produk, (7) revisi produk, (8) uji coba pemakaian, (9) revisi produk, dan (10) produksi.

Adapun 6 langkah penelitian pengembangan yang diinterpretasikan dari desain pengembangan Sugiyono oleh peneliti dapat dilihat pada gambar berikut. 


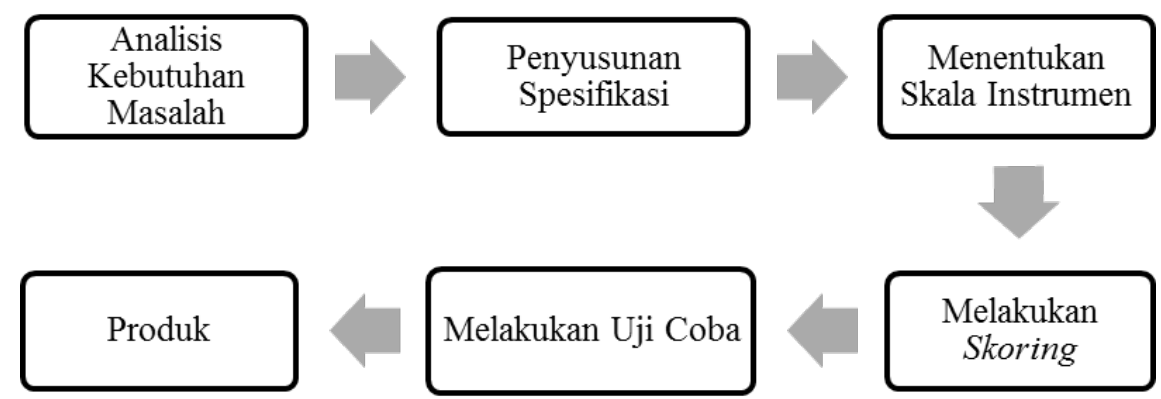

Berdasarkan beberapa kajian metode pengembangan di atas, peneliti menarik kesimpulan mengenai langkah-langkah pengembangan untuk menghasilkan model instrumen penilaian sikap yang didasarkan pada kajian nilai-nilai moral pada novel Rasiah Kodeu Binér karya Dadan Sutisna dan novel Petualangan Hati Jelajahi Pelangi karya Sherina Salsabila yang sesuai dengan kriteria serta mengacu pada bentuk penilaian sikap Kurikulum 2013, maka penyusunannya harus dilakukan secara sistematis dan sesuai dengan kaidah dan prosedur yang baik.

Langkah-langkah pengembangan konsep bentuk instrumen penilaian sikap pada apresiasi sastra anak yang lebih rinci terdapat 6 tahapan, yaitu:

1. Analisis kebutuhan masalah

Berdasarkan pada kebutuhan guru-guru yang mengampu mata pelajaran Bahasa Indonesia di tingkat Sekolah Dasar mengenai proses membuat instrumen penilaian sikap yang masih terasa sulit untuk dilakukan oelh guru-guru yang beban tugas tidak hanya sekedar menilai siswa. Guru ingin membuat instrumen penilain sikap dengan mudah dan sesuai dengan kegiatan belajar mengajar dan kondisi anak didiknya yang tentu saja mengacu dan disesuaikan juga dengan rambu-rambu bentuk penilaian sikap Kurikulum 2013.

2. Penyusunan Spesifikasi

Mengelaborasi atau mendefinisikan siapa yang akan dinilai atau apa yang akan dikembangkan, apakah sikap, karakter, kemampuan sastra? Adapun teknik dalam penilain sikap berdasarkan pada Kurikulum 2013, yaitu teknik observasi, teknik penilaian diri sendiri, penilaian antar teman, jurnal harian.

Berdasarkan acuan instrumen penilaian sikap pada Kurikulum 2013 terdapat empat teknik penilaian sikap yang dilakukan oleh guru juga siswa, antar lain; 1) Teknik observasi merupakan teknik penilaian observasi dapat digunakan untuk menilai ketercapaian sikap spiritual dan sikap sosial. Observasi dilaksanakan oleh guru secara langsung tanpa perantara orang lain. Sedangkan observasi tidak langsung dengan bantuan orang lain, seperti guru lain, orang tua, siswa, dan karyawan sekolah. 2) Teknik penilain diri merupakan merupakan teknik penilaian dengan cara meminta 
peserta didik mengemukakan kelebihan dan kekurangan dirinya, penguasaan kompetensi yang ditargetkan, dan menghargai, menghayati serta pengamalan perilaku berkepribadian Jujur, Jujur adalah perilaku yang didasarkan pada upaya menjadikan dirinya sebagai orang yang selalu dapat diper-caya dalam perkataan, tindakan, dan pekerjaan. 4) Teknik penilaian sejawat atau antar teman merupakan teknik penilaian dengan cara meminta peserta didik untuk saling menilai terkait dengan pencapaian kompetensi. 5) Teknik penilain jurnal harian. Jurnal merupakan catatan pendidik di dalam dan di luar kelas yang berisi informasi hasil pengamatan tentang kekuatan dan kelemahan peserta didik yang berkaitan dengan sikap dan perilaku. Namun, yang dikembangkan dalam penelitian ini adalah teknik penilain diri (self assesment) sikap terhadap sikap spiritual dan sosial yang memanfaatkan nilai-nilai moral dalam novel anak pada pembelajaran apresiasi sastra anak.

Pemilihan spesifikasi untuk pengembangan instrumen penilaian sikap lebih dikhususkan pada teknik penilaian diri (self assesment). Dalam Penilain diri, peserta didik diminta untuk melakukan penilaian berdasarkan kriteria atau acuan yang telah disiapkan pada instrumen yang dibuat. Instrumen yang digunakan adalah lembar penilaian diri dengan skala sikap (attitude scale) dengan menggunakan skala Likert yang disertai rubrik.

Dalam menyusun spesifikasi instrumen perlu memperhatikan empat hal, yaitu: (1) Tujuan Pengukuran: tujuan pengukuran dengan menggunakan instrumen penilaian sikap siswa nilai ketuhanan dan kecintaan terhadap lingkungan yang telah dikembangkan adalah untuk mengukur sikap siswa yang berkaitan dengan nilai-nilai moral yang terdapat pada novel anak serta indikator penilaiasn sikap Kurikulum 2013. (2) Kisi-kisi: kisi-kisi yang dikembangkan diawali dengan membuat pemetaan indikator berdasarkan analisis kajian nilai-nilai moral novel anak dan indikator penilaiasn sikap Kurikulum 2013. Selanjutnya, dengan adanya indikator, dapat dikembangkan kisi-kisi produk instrumen penilaian sikap ini, yakni dengan membuat pernyataan setiap indikator. (3) Bentuk dan format instrumen: pernyataan yang telah dibuat di dalam sebuah kisi-kisi dapat dirangkai menjadi sebuah lembar penilaian diri dengan bentuk dan format yang telah ditentukan. Butir pernyataan disusun dalam sebuah tabel yang terdiri dari kolom pernyataan dan jawaban dengan 5 alternatif jawaban. (4) Panjang Instrumen: jumlah pernyataan produk instrumen penilaian sikap siswa sebanyak 8 butir pernyataan atau lebih tergantung pada masing-masing guru membuatnya yang tentu saja disesuaikan dengan proses pembelajaran.

3. Menentukan Skala Instrumen

Skala penilaian sikap yang digunakan adalah skala Likert dengan lima alternatif jawaban. Skala ini disusun dalam suatu bentuk pernyataan dan diikuti oleh pilihan respon yang menunjukkan tingkatan. Pilihan responnya adalah SS (sangat 
setuju), S (setuju), R (ragu), TS (tidak setuju), STS (sangat tidak setuju).

4. Melakukan skoring

Penskoran pilihan jawaban skala Likert bergantung pada sifat pernyataan. Terdapat dua sifat pernyataan, yaitu pernyataan yang bersifat positif dan negatif. Untuk pernyataan yang bersifat positif, skor jawaban adalah: $\mathrm{SS}=4$; $\mathrm{S}=3$; $\mathrm{R}=$ 2 ; $\mathrm{TS}=1$; dan $\mathrm{STS}=0$. Untuk pernyataan yang bersifat negatif adalah sebaliknya, yaitu: $\mathrm{SS}=0 ; \mathrm{S}=1 ; \mathrm{R}=2$; $\mathrm{TS}=3$; dan $\mathrm{STS}$ $=4$.

Di bawah ini adalah contoh konsep bentuk instrumen penilaian sikap pada apresiasi sastra anak yang menagacu pada bentuk kompetensi penilaian sikap Kurikulum 2013 serta kajian nilai-nilai moral yang terdapat pada novel Rasiah Kodeu Binér karya Dadan Sutisna dan novel Petualangan Hati Jelajahi Pelangi karya Sherina Salsabila. Berikut penggalan kutipan novel.

Pada hari Sabtu sore sesudah salat bersama ayah dan ibu, aku dan kawan-kawanku pergi bermain di tanah lapang. Kawanku dengan sabar menungguku untuk mengerjakan salat. Terima kasih Aira. Kataku dengan senang. (HJP/hal. 10)

\begin{tabular}{|c|c|c|c|c|c|c|}
\hline \multirow{2}{*}{ No. } & \multirow{2}{*}{ Pernyataan } & \multicolumn{5}{|c|}{ Pilihan Jawaban } \\
\hline & & SS & $\mathbf{S}$ & $\mathbf{R}$ & TS & STS \\
\hline 1. & $\begin{array}{l}\text { Sebagai anak-anak perlu } \\
\text { bermain jangan hanya belajar } \\
\text { supaya perkembangan } \\
\text { jiwanya normal. }\end{array}$ & & & & & \\
\hline 2. & $\begin{array}{l}\text { Biasakan hidup kebersamaan } \\
\text { jangan biasakan hidup jalan } \\
\text { sendiri (egois) }\end{array}$ & & & & & \\
\hline 3. & $\begin{array}{l}\text { Menjalankan ibadah tepat } \\
\text { waktu. }\end{array}$ & & & & & \\
\hline 4. & $\begin{array}{l}\text { Kalau salat diupayakan } \\
\text { berjamaah dengan seisi } \\
\text { rumah. }\end{array}$ & & & & & \\
\hline 5. & $\begin{array}{l}\text { Sebagai anak sekolah } \\
\text { hendaknya bermain-main } \\
\text { pada Sabtu sore bukan rabu } \\
\text { sore. }\end{array}$ & & & & & \\
\hline 6. & $\begin{array}{l}\text { Hendaknya pergi bermain } \\
\text { sesudah salat. }\end{array}$ & & & & & \\
\hline 7. & $\begin{array}{l}\text { Jika bermain kiranya di tanah } \\
\text { lapang, bukan di jalan raya. }\end{array}$ & & & & & \\
\hline 8. & $\begin{array}{l}\text { Menunggu teman berbeda } \\
\text { agama yang sedang } \\
\text { mengerjakan ibadah. }\end{array}$ & & & & & \\
\hline & Jumlah skor & & & & & \\
\hline
\end{tabular}


Keterangan skor:

$\begin{array}{ll}\mathrm{SS}=4 & \mathrm{TS}=1 \\ \mathrm{~S}=3 & \mathrm{STS}=0 \\ \mathrm{R}=2 & \end{array}$

Contoh bentuk instrumen penilaian sikap pada variabel teknik penilain diri (self assesment) dibuat sederhana untuk memudahkan para guru membuat sendiri instrumen penilaian sikap pada proses pembelajaran yang tentu saja dikaitkan dengan kegiatan belajar mengajar serta materi pada saat pembelajaran berlangsung.

Pada umumnya dalam dunia pendidikan dan bidang pengajaran, penilaian adalah suatu program untuk memberikan pendapat dan penentuan arti atau faedah suatu pengalaman. Yang dimaksud dengan pengalaman adalah pengalaman yang diperoleh berkat proses pendidikan. Pengalaman tersebut tampak pada perubahan tingkah laku atau pola kepribadian siswa.

Berdasarkan hasil pengembangan instrumen penilaian sikap pada apresiasi sastra anak, dapat digunakan sebagai alternatif penilaian sikap pada siswa melalui pemanfaatan nilai-nilai yang terkandung dalam sastra anak. Guru akan lebih baik dalam menilai sikap siswa pada apresiasi sastra. Guru dapat menyesuaikan instrumen penilaian sikap pada apresiasi sastra anak sesuai dengan materi mengenai sastra anak yang akan diberikan pada siswa. Sehingga dalam pembelajaran baik guru dan siswa akan bersentuhan langsung dengan karya sastra itu sendiri.

Mengkaji kesulitan guru dalam memahami kriteria penilaian sikap dari pedoman penilaian sikap yang ada, maka perlu berusaha untuk menyusun instrumen penilaian sikap yang mudah dipahami dan mudah digunakan. Pengembangan instrumen penilaian sikap ini akan mengadopsi penilaian sikap pada kompetensi penilaian sikap Kurikulum 2013 serta dikaitkan dengan aspek nilai-nilai moral yang terdapat di dalam karya sastra anak.

Pengembangan instrumen penilaian sikap pada apresiasi sastra anak dilakukan dengan beberapa langkah atau tahap. Langkahlangakah tersebut didasarkan pada konsep pengembangan beberapa tokoh lalu disimpulkan sendiri oleh peneliti untuk membuat yang lebih sederhana.

Model konsep bentuk instrumen penilaian sikap terutama pada variabel teknik penilai diri sendiri (self assesment) yaitu mengacu pada indikator bentuk kompetensi penilaian sikap Kurikulum 2013 dan kajian nilai-nilai moral yang terdapat pada novel Rasiah Kodeu Binér karya Dadan Sutisna dan novel Petualangan Hati Jelajahi Pelangi karya Sherina Salsabila. Dengan memanfaatkan nilai-nilai yang terkandung dalam sastra anak, maka akan memudahkan para guru mengevaluasi sikap dalam apresiasi sastra anak yaitu dengan konsep bentuk penilaian sikap yang memanfaatkan sastra anak sebagai landasan indikator instrumennya. Instrumen penilaian 
sikap pada apresiasi sastra anak ini juga dapat digunakan pada penilaian sikap pada apresiasi sastra pada umumnya.

\section{DAFTAR PUSTAKA}

Abidin, Yunus. 2010. Pembelajaran Bahasa Berbasis Pendidikan Karakter. Bandung: Refika Aditama.

Ampera, Taufik. 2010. Pengajaran Sastra. Teknik Mengajar Sastra Anak Berbasis Aktivitas. Bandung: Widya Padjajaran.

Nurgiyantoro, Burhan. 2011. Penilain Otentik dalam Pembelajaran Bahasa. Yogyakarta: Gadjah Mada University Press.

Salsabila, Sherina. 2013. Petualangan Hati Jelajahi Pelangi. Jakarta: Zettu.
Sudjana, Nana. 2011. Penilaian Hasil Proses Belajar mengajar. Bandung: Rosdakarya.

Sugiyono. 2013. Metode Penelitian dan Pengembangan. Yogyakarta: Alfabeta.

Suryabrata, Sumadi. 2012. Metodologi Penelitian. Jakarta: PT. Raja Grafindo Persada.

Sutisna, dadan. 2010. Rasiah Kodeu Biner. Bandung: Kiblat Buku Utama.

Tarigan, Henry Guntur. 2011. Dasardasar Psikosastra. Bandung: Angkasa. 